\title{
Publisher Correction: Observation of dark states in a superconductor diamond quantum hybrid system
}

Xiaobo Zhu, Yuichiro Matsuzaki, Robert Amsüss, Kosuke Kakuyanagi, Takaaki Shimo-Oka, Norikazu Mizuochi, Kae Nemoto, Kouichi Semba, William J. Munro \& Shiro Saito

Nature Communications 5:3524 doi: 10.1038/ncomms4524 (2014); Published 8 Apr 2014; Updated 29 Mar 2018

The original HTML version of this Article had an incorrect article number of 3424; it should have been 3524 . This has now been corrected in the HTML; the PDF version of the Article was correct from the time of publication.

\footnotetext{
(c) (i)

Open Access This article is licensed under a Creative Commons Attribution 4.0 International License, which permits use, sharing, adaptation, distribution and reproduction in any medium or format, as long as you give appropriate credit to the original author(s) and the source, provide a link to the Creative Commons license, and indicate if changes were made. The images or other third party material in this article are included in the article's Creative Commons license, unless indicated otherwise in a credit line to the material. If material is not included in the article's Creative Commons license and your intended use is not permitted by statutory regulation or exceeds the permitted use, you will need to obtain permission directly from the copyright holder. To view a copy of this license, visit http://creativecommons.org/licenses/by/4.0/
}

(C) The Author(s) 2018 